Prepared in cooperation with Colorado Department of Transportation

\title{
Probability and Volume of Potential Postwildfire Debris Flows in the 2012 Waldo Canyon Burn Area near Colorado Springs, Colorado
}

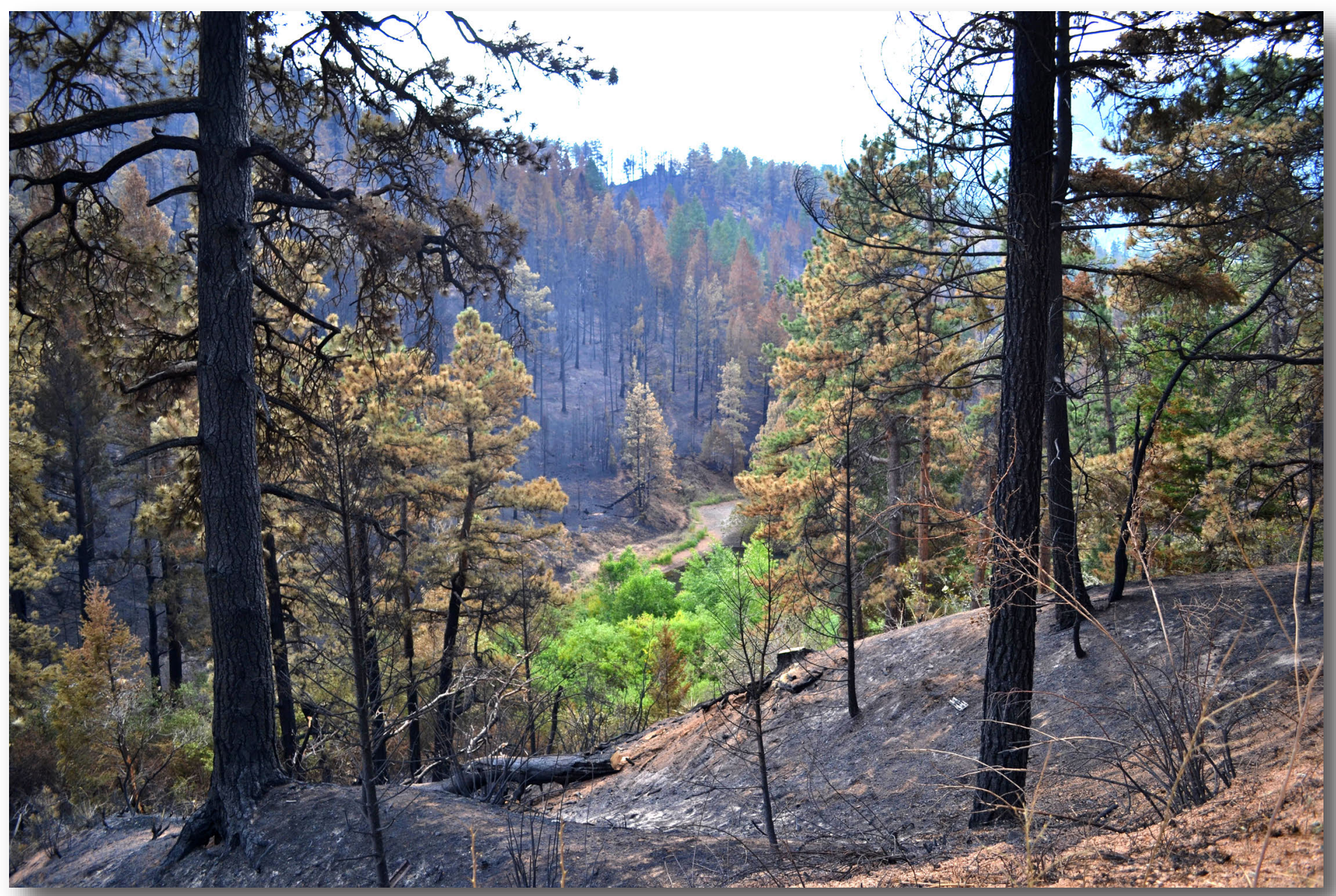

Open-File Report 2012-1158

U.S. Department of the Interior U.S. Geological Survey 
Cover: Wellington Gulch, view is looking downstream from Wellington Gulch Road. Photo by John G. Elliott, 2 July 2012. 


\section{Probability and Volume of Potential Postwildfire Debris Flows in the 2012 Waldo Canyon Burn Area near Colorado Springs, Colorado}

By Kristine L. Verdin, Jean A. Dupree, and John G. Elliott

Prepared in cooperation with Colorado Department of Transportation

Open-File Report 2012-1158

U.S. Department of the Interior

U.S. Geological Survey 


\section{U.S. Department of the Interior KEN SALAZAR, Secretary}

\section{U.S. Geological Survey Marcia K. McNutt, Director}

U.S. Geological Survey, Reston, Virginia: 2012

For product and ordering information: World Wide Web: http://www.usgs.gov/pubprod

Telephone: 1-888-ASK-USGS

For more information on the USGS-the Federal source for science about the Earth, its natural and living resources, natural hazards, and the environment: World Wide Web: http://www.usgs.gov

Telephone: 1-888-ASK-USGS

Suggested citation:

Verdin, K.L., Dupree, J.A, and Elliott, J.G., Probability and volume of potential postwildfire debris flows in the 2012 Waldo Canyon Burn Area near Colorado Springs, Colorado: U.S. Geological Survey Open-File Report 2012-1158, 8 p.

Any use of trade, product, or firm names is for descriptive purposes only and does not imply endorsement by the U.S. Government.

Although this report is in the public domain, permission must be secured from the individual copyright owners to reproduce any copyrighted material contained within this report. 


\section{Contents}

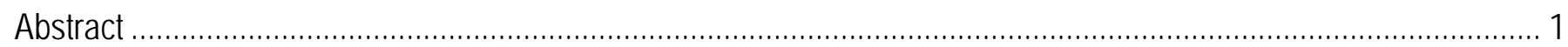

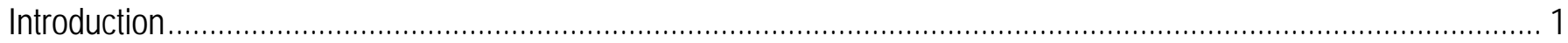

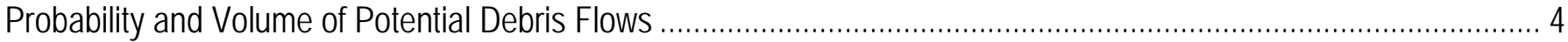

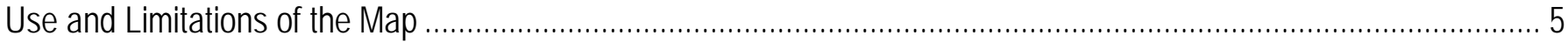

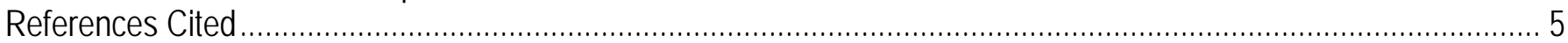

\section{Figure}

1. Location and severity of the 2012 Waldo Canyon fire near Colorado Springs, Colo

\section{Table}

1. Estimated debris-flow probabilities and volumes for the 2012 Waldo Canyon fire near Colorado Springs, Colo

\section{Plates}

1. Estimated probability of potential postwildfire debris flows in the 2012 Waldo Canyon Burn Area near Colorado Springs, Colorado...... link

2. Estimated volumes of potential postwildfire debris flows in the 2012 Waldo Canyon Burn Area near Colorado Springs, Colorado...... link 


\section{Conversion Factors}

SI to Inch/Pound

\begin{tabular}{|c|c|c|}
\hline Multiply & By & To obtain \\
\hline \multicolumn{3}{|c|}{ Length } \\
\hline millimeter (mm) & 0.03937 & inch (in.) \\
\hline meter (m) & 3.281 & foot $(\mathrm{ft})$ \\
\hline meter (m) & 1.094 & yard (yd) \\
\hline kilometer (km) & 0.6214 & mile (mi) \\
\hline \multicolumn{3}{|c|}{ Area } \\
\hline square meter $\left(\mathrm{m}^{2}\right)$ & 0.0002471 & acre \\
\hline square kilometer $\left(\mathrm{km}^{2}\right)$ & 0.3861 & square mile $\left(\mathrm{mi}^{2}\right)$ \\
\hline \multicolumn{3}{|c|}{ Volume } \\
\hline cubic meter $\left(\mathrm{m}^{3}\right)$ & 35.31 & cubic foot $\left(\mathrm{ft}^{3}\right)$ \\
\hline cubic meter $\left(\mathrm{m}^{3}\right)$ & 1.308 & cubic yard $\left(\mathrm{yd}^{3}\right)$ \\
\hline cubic meter $\left(\mathrm{m}^{3}\right)$ & 0.0008107 & acre-foot (acre-ft) \\
\hline \multicolumn{3}{|c|}{ Flow rate } \\
\hline millimeter per year (mm/yr) & 0.03937 & inch per year (in/yr) \\
\hline
\end{tabular}

Vertical coordinate information is referenced to the North American Vertical Datum of 1988 (NAVD 88). Horizontal coordinate information is referenced to the North American Datum of 1983 (NAD 83). 


\title{
Probability and Volume of Potential Postwildfire Debris Flows in the 2012 Waldo Canyon Burn Area near Colorado Springs, Colorado
}

\author{
By Kristine L. Verdin, Jean A. Dupree, and John G. Elliott
}

\begin{abstract}
This report presents a preliminary emergency assessment of the debris-flow hazards from drainage basins burned by the 2012 Waldo Canyon fire near Colorado Springs in El Paso County, Colorado. Empirical models derived from statistical evaluation of data collected from recently burned basins throughout the intermountain western United States were used to estimate the probability of debris-flow occurrence and potential volume of debris flows along the drainage network of the burned area and to estimate the same for 22 selected drainage basins along U.S. Highway 24 and the perimeter of the burned area. Input data for the models included topographic parameters, soil characteristics, burn severity, and rainfall totals and intensities for a (1) 2-year-recurrence, 1-hour-duration rainfall, referred to as a 2-year storm (29 millimeters); (2) 10-year-recurrence, 1-hour-duration rainfall, referred to as a 10-year storm (42 millimeters); and (3) 25-year-recurrence, 1-hour-duration rainfall, referred to as a 25year storm (48 millimeters).

Estimated debris-flow probabilities at the pour points of the drainage basins of interest ranged from less than 1 to 54 percent in response to the 2-year storm; from less than 1 to 74 percent in response to the 10-year storm; and from less than 1 to 82 percent in response to the 25-year storm. Basins and drainage networks with the highest probabilities tended to be those on the southern and southeastern edge of the burn area where soils have relatively high clay contents and gradients are steep. Nine of the 22 drainage basins of interest have greater than a 40-percent probability of producing a debris flow in response to the 10-year storm. Estimated debris-flow volumes for all rainfalls modeled range from a low of 1,500 cubic meters to a high of greater than 100,000 cubic meters. Estimated debris-flow volumes increase with basin size and distance along the drainage network, but some smaller drainages were also predicted to produce substantial volumes of material. The predicted probabilities and some of the volumes predicted for the modeled storms indicate a potential for substantial debrisflow impacts on structures, reservoirs, roads, bridges, and culverts located both within and immediately downstream from the burned area. U.S. Highway 24, on the southern edge of the burn area, is also susceptible to impacts from debris flows.
\end{abstract}

\section{Introduction}

The objective of this report is to present a preliminary emergency assessment of the debris-flow hazards from basins burned by the 2012 Waldo Canyon fire near Colorado Springs in El Paso County, Colorado (Colo.). Debris flows have been documented after many fires in the western United States (Cannon and others, 2010) and can threaten lives, property, infrastructure, aquatic habitats, and water supplies. Wildfires can denude hillslopes of vegetation and change soil properties that affect watershed 
hydrology and sediment-transport processes. Even small postwildfire rainstorms can increase overland runoff that erodes soil, rock, ash, and vegetative debris from hillslopes (Cannon and others, 2008). This increased runoff concentrates in stream channels and entrains the sediment that can lead to the generation of destructive debris flows. Debris flow hazards are most significant up to 3 years (yr) following wildfires (Susan Cannon, U.S. Geological Survey, written commun., 2010).

Field inspection of the southern edge of the Waldo Canyon burn area immediately adjacent to U.S. Highway 24 suggests some debris-flow activity prior to 2012 in an unnamed basin (shown with pour point 15 on plates 1 and 2) that is one of the eastern tributaries to Fountain Creek. Little evidence of previous debris flows was found at the mouths of Fountain Creek tributaries further west along U.S. Highway 24, although a number of alluvial fans and fluvial deposits composed predominantly of decomposed granite were identified. No inspections were made of most tributaries above their lower reaches; therefore, it was not determined whether previous debris-flow evidence existed in other tributary locations. However, Wellington Gulch, a tributary to Fountain Creek, was examined in its lower 1-kilometer $(\mathrm{km})$ reach. Most sedimentary deposits in this reach appeared to be of alluvial, and not debris-flow, origin.

This report, done in cooperation with the Colorado Department of Transportation, presents an assessment of the debris-flow hazards from drainage basins burned in 2012 by the Waldo Canyon wildfire west of Colorado Springs, Colo. The Waldo Canyon wildfire burned more than 18,000 acres within a burn perimeter of more than 19,000 acres (fig. 1). This report provides estimates of the predicted probability of debris-flow occurrence and volume of debris along the drainage network throughout the entire area, as well as estimates for drainage basins above 22 selected basin outlets in response to three design storms: (1) 2-year-recurrence, 1-hour duration rainfall of 29 millimeters (mm), referred to as a 2-year storm (a 50-percent chance of occurrence in any given year); (2) 10-yearrecurrence, 1-hour-duration rainfall of $42 \mathrm{~mm}$, referred to as a 10-year storm (a 10-percent chance of occurrence in any given year); and (3) 25-year-recurrence, 1-hour-duration rainfall of $48 \mathrm{~mm}$, referred to as a 25-year storm (a 4-percent chance of occurrence in any given year). These design events were defined from data and methods detailed in the National Oceanic and Atmospheric Administration's (NOAA) Precipitation-Frequency Atlas of the Western United States (Miller and others, 1973).

A set of empirical equations (models) documented in Cannon and others (2010) and derived from statistical evaluation of data collected from recently burned basins throughout the intermountain western United States were used to estimate the probability of debris-flow occurrence and volumes of debris flows along the drainage network and for selected drainage basins. The regression equation of debris-flow probability (eq. 1) is as follows:

$$
P=e^{x} /\left(1+e^{x}\right),
$$

where

$$
\begin{gathered}
P \quad \text { is the probability of debris-flow occurrence in fractional form; and } \\
x=-0.7+0.03(\% S G 30)-1.6(R)+0.06(\% A B)+0.07(I)+0.2(\% C)-0.4(L L),
\end{gathered}
$$

where

$\% S G 30$ is the percentage of the drainage-basin area with slope equal to or greater than 30 percent;

$R$ is drainage-basin ruggedness: the change in drainage-basin elevation (meters) divided by the square root of the drainage-basin area (square meters) (Melton, 1965);

$\% \mathrm{AB}$ is the percentage of drainage-basin area burned at moderate to high severity (data for this investigation from David Young, U.S. Department of Agriculture Forest Service, written commun., 2012); 
$I$ is average storm intensity (calculated by dividing total storm rainfall [Miller and others, 1973] by the storm duration, in millimeters per hour);

$\% C$ is clay content of the soil (percent) (National Soil Survey Center, 1991); and

$L L$ is the liquid limit of the soil (percentage of soil moisture by weight) (National Soil Survey Center, 1991).

Cannon and others (2010) also developed an empirical model that can be used to estimate the volume of debris flow that would likely be produced from recently burned drainage basins:

$$
\text { Ln } V=7.2+0.6(\ln S G 30)+0.7(A B)^{0.5}+0.2(T)^{0.5}+0.3 \text {, }
$$

where

$V$ is the debris-flow volume, including water, sediment, and debris (cubic meters);

$S G 30$ is the area of a drainage basin with slopes equal to or greater than 30 percent (square kilometers);

$A B$ is the drainage-basin area burned at moderate to high severity (square kilometers);

$T$ is the total storm rainfall (millimeters); and

0.3 is a bias-correction factor that changes the predicted estimate from a median to a mean value (Helsel and Hirsch, 2002).

Values for both probability and volume were obtained along drainage networks using the continuous parameterization technique (Verdin and Greenlee, 2003; Verdin and Worstell, 2008). With this technique, estimates of debris-flow probability and volume (Cannon and others, 2010) were obtained for every 10-meter (m) pixel along the drainage network (plates 1 and 2) as a function of conditions in the drainage basin at elevations higher than each $10-\mathrm{m}$ pixel. This technique was developed as an alternative to basin-characterization approaches used in the past (for example, Cannon and others, 2009), which require definition of outlets (pour points) and their corresponding basins at the beginning of the analysis. The technique used here allows for a synoptic view of conditions throughout the entire study area, which can be used to identify specific 10 -m cells or stream reaches that might be in danger; the technique also aids in locating sites for installation of precipitation and streamflow gages and in identifying potential erosion-mitigation sites.

The base layer upon which the continuous-parameterization layers are built is the 1/3-arc-second National Elevation Dataset (Gesch and others, 2002). This digital elevation model (DEM) was projected into a Colorado-appropriate projection system (UTM, Zone 13) and processed using standard DEMconditioning tools in ArcGIS (ESRI, 2009) and RiverTools (Rivix, 2012). Once the overland flow structure was derived using the DEM (in the form of a flow-direction matrix), the independent variables driving the probability and volume equations were evaluated for every grid cell within the extent of the DEM. Values for all of the independent variables driving the debris-flow and volume equations were obtained using the continuous-parameterization approach. Once the surfaces of the independent variables were developed, the probability and volume equations were solved using map algebra for each grid cell along the drainage network. Identification of the probability or volume of a debris flow at locations within the study area can be obtained by querying the derived surfaces.

Following calculation of debris-flow probabilities and volumes continuously along the drainage networks, 22 basins of interest along U.S. Highway 24 and along the northern and eastern edges of the burn perimeter were identified. Debris-flow probabilities and volumes were extracted from the probability and volume surface for these locations. These values are shown in plates 1 and 2 and summarized in table 1. 


\section{Probability and Volume of Potential Debris Flows}

In response to the 2-year storm, two basins affected by the burn (basins 15 and 17; table 1) were identified as having probabilities of debris-flow occurrence greater than 50 percent, and an additional 5 basins (13,14,19, 20, and 21) had probabilities between 30 and 50 percent. All seven of these basins are located on the southern edge of the burn area and drain toward U.S. Highway 24. These are all moderately-size basins with drainage areas ranging from 0.7 to 6.8 square kilometers $\left(\mathrm{km}^{2}\right)$. Estimated volumes of debris flows for these seven basins ranged from 6,200 to 62,000 cubic meters $\left(\mathrm{m}^{3}\right)$. These values indicate a substantial risk of debris flow in response to a storm with a 50-percent chance of affecting the area each year.

The 10-year storm resulted in more basins with a higher probability of debris flow (plate 1, table 1). Four basins (15, 17, 20, and 21) had probabilities of debris flow in excess of 60 percent with corresponding volume estimates from $10,000 \mathrm{~m}^{3}$ to $52,000 \mathrm{~m}^{3}$. These basins are located on the southern edge of the burned area, draining toward U.S. Highway 24 and range in size from 0.9 to $4.5 \mathrm{~km}^{2}$. Five additional basins had probabilities of debris flow between 40 and 59 percent. These basins also drain to the south (toward U.S. Highway 24) as well as to the east (Douglas Creek[10] and Queens Canyon [12]) with potential impacts on the urbanized areas of western Colorado Springs. The basins with probabilities in excess of 40 percent were modeled as producing volumes from 7,700 to over 100,000 $\mathrm{m}^{3}$, indicating a substantial hazard should a debris flow occur. The volumes and probabilities calculated for these basins indicate a substantial risk of debris flow in response to a storm with a 10-percent chance of occurring each year.

The additional detail provided by the continuous-parameterization technique can be seen in plate 1. As an example, the estimated probabilities at the pour point for Queens Canyon (12) is 45 percent. Examination of the drainage network upstream from the pour point for Queens Canyon reveals many drainage channels with estimated probabilities above 60 percent and several with probabilities between 45 and 60 percent. These channels could pose more serious, localized debris-flow hazards than would be expected at the pour point of the basin.

The 25-year storm shows additional basins with higher probabilities of debris flows than would result from the 2-year and 10-year storms (table 1). Higher debris-flow volumes are likely to be produced in response to this storm as well. Seven basins show a probability of debris flow in excess of 60 percent. These seven basins all drain to U.S. Highway 24. An additional two basins, draining east toward Colorado Springs, have probabilities between 40 and 59 percent. For the 25-year storm, only seven out of the 22 basins of interest are modeled as expected to produce debris-flow volumes less than about $10,000 \mathrm{~m}^{3}$. Four of these basins drain toward Rampart Reservoir in the the northwest corner of the burn area. This area is characterized by relatively less-steep terrain and soils with lower clay content. The other three basins are small basins which drain toward Colorado State Highway 24, and have areas from 0.3 to $0.7 \mathrm{~km}^{2}$. Probabilities and volumes calculated in response to the 25-year storm indicate that should this storm occur (there is a 4-percent chance each year), destructive debris flows can be expected from many of the drainage basins burned by the Waldo Canyon fire, particularly on the southern and eastern edges of the burn area.

The combined probabilities and volumes for basins modeled on the southern edge (draining toward U.S. Highway 24) and eastern edge (draining towards western Colorado Springs) of the burned area in response to the all three storm magnitudes indicate a potential for debris-flow impacts on buildings, roads, bridges, culverts, and reservoirs located both within and immediately downstream from the burned area. In addition, even small debris flows that affect structures and reservoirs at the basin outlets could cause damage. 


\section{Use and Limitations of the Map}

This assessment provides estimates of debris-flow probability and volume for drainage basins burned by the Waldo Canyon fire in response to three design storms based on predictive models developed from data from burned areas throughout the western United States. In basins where the predominant rock type is well-decomposed Pikes Peak granite, it is possible that sediment-laden floods would be more likely than debris flows. Basins 1 to 8 and 19 to 22 (plates 1 and 2) lie completely within Pikes Peak granite. The remaining basins (9 to 18) lie partially within Pikes Peak granite (Stoeser and others, 2005). In basins with well-decomposed Pikes Peak granite, the debris-flow modeling produced in this study will help identify areas of concern for both debris-flows and sediment-laden floods. Larger, less-frequent storms are more likely to produce much larger debris flows. Because individual storms may not affect the entire area at any given time, debris flows may not be produced from all basins during storms. The estimates are meant to be valid for up to 3 yr after the fire (Susan Cannon, U.S. Geological Survey, written commun., 2010).

The plates may be used to prioritize areas where emergency-flood warnings or erosion mitigation may be needed prior to rainstorms within these basins, their outlets, or areas downstream from these basins. This assessment evaluates only postwildfire debris flows (Cannon and others, 2007). Substantial hazards from flash floods without debris flow may persist for many years after a fire.

This work is preliminary and is subject to revision. It is being provided owing to the need for timely "best science” information. The assessment is provided on the condition that neither the U.S. Geological Survey nor the United States Government may be held liable for any damages resulting from the authorized or unauthorized use of the assessment.

\section{References Cited}

Cannon, S.H., Gartner, J.E., and Michael, J.A., 2007, Methods for the emergency assessment of debrisflow hazards from basins burned by the fires of 2007, southern California: U.S. Geological Survey Open-File Report 2007-1384, 10 p. (Also available at http://pubs.usgs.gov/of/2007/1384/.)

Cannon, S.H., Gartner, J.E., Rupert, M.G., Michael, J.A., Staley, D.B., and Worstell, B.B., 2009, Emergency assessment of postfire debris-flow hazards for the 2009 Station Fire, San Gabriel Mountains, Southern California: U.S. Geological Survey Open-File Report 2009-1227, 27 p. (Also available at http://pubs.usgs.gov/of/2009/1227/.)

Cannon, S.H., Gartner, J.E., Wilson, R.C., and Laber, J.L., 2008, Storm rainfall conditions for floods and debris flows from recently burned areas in southwestern Colorado and southern California: Geomorphology, v. 96, p. 250-269, doi:10.1019/j.geomorph.2008.03.019.

Cannon, S.H., Gartner, J.E., Rupert, M.G., Michael, J.A., Rea, A.H., and Parrett, C., 2010, Predicting the probability and volume of postwildfire debris flows in the intermountain western United States: Geological Society of America Bulletin, v. 122, p. 127-144.

ESRI, 2009, ArcGIS v. 9.3: Redlands, Calif., ESRI.

Gesch, D., Oimoen, M., Greenlee, S., Nelson, C., Steuck, M., and Tyler, D., 2002, The national elevation dataset: Photogrammetric Engineering and Remote Sensing, v. 68, no. 1, p. 5-11.

Helsel, D.R., and Hirsch, R.M., 2002, Statistical methods in water resources: New York, N.Y., Elsevier Studies in Environmental Science, v. 49, 529 p.

Melton, M.A., 1965, The geomorphic and paleoclimate significance of alluvial deposits in southern Arizona: Journal of Geology, v. 73, p. 1-38. 
Miller, J.F., Frederick, R.H., and Tracey, R.J., 1973, Precipitation-frequency atlas of the western United States, v. 3-Colorado: Silver Spring, Md., U.S. Department of Commerce, National Oceanic and Atmospheric Administration Atlas 2, National Weather Service, 47 p.

Rivix, LLC, 2012, RiverTools 3.0.3: Broomfield, Colo., Rivix, LLC, accessed July, 2012, at http://rivix.com.

National Soil Survey Center, 1991, State Soil Geographic (STATSGO) database—Data use information: U.S. Department of Agriculture, National Resources Conservation Service, Miscellaneous Publication 1492, 110 p. [Revised July, 1994]

Stoeser, D.B. , Green, G.N. , Morath, L.C. , Heran, W.D. , Wilson, A.B. , Moore, D.W. , and Van Gosen, B.S., 2005, Preliminary integrated geologic map databases for the United States Central States-Montana, Wyoming, Colorado, New Mexico, Kansas, Oklahoma, Texas, Missouri, Arkansas, and Louisiana, state of Colorado: U.S. Geological Survey Open-File Report 2005-1351, unpaged. (Also available at $h t t p: / / p u b s . u s g s . g o v / o f / 2005 / 1351 /$.

Verdin, K.L., and Greenlee, S., 2003, Continuous parameterization using EDNA, in 2003 ESRI User's Conference, San Diego, Calif., July 7-11, 2003, Proceedings: Redlands, Calif., ESRI, accessed June, 2012, at http://gis.esri.com/library/userconf/proc03/p0617.pdf.

Verdin, K.L., and Worstell, B., 2008, A fully distributed implementation of mean annual streamflow regional regression equations: Journal of the American Water Resources Association, v. 44, p. 15371547, doi: 10.1111/j.1752-1688.2008.00258.x 


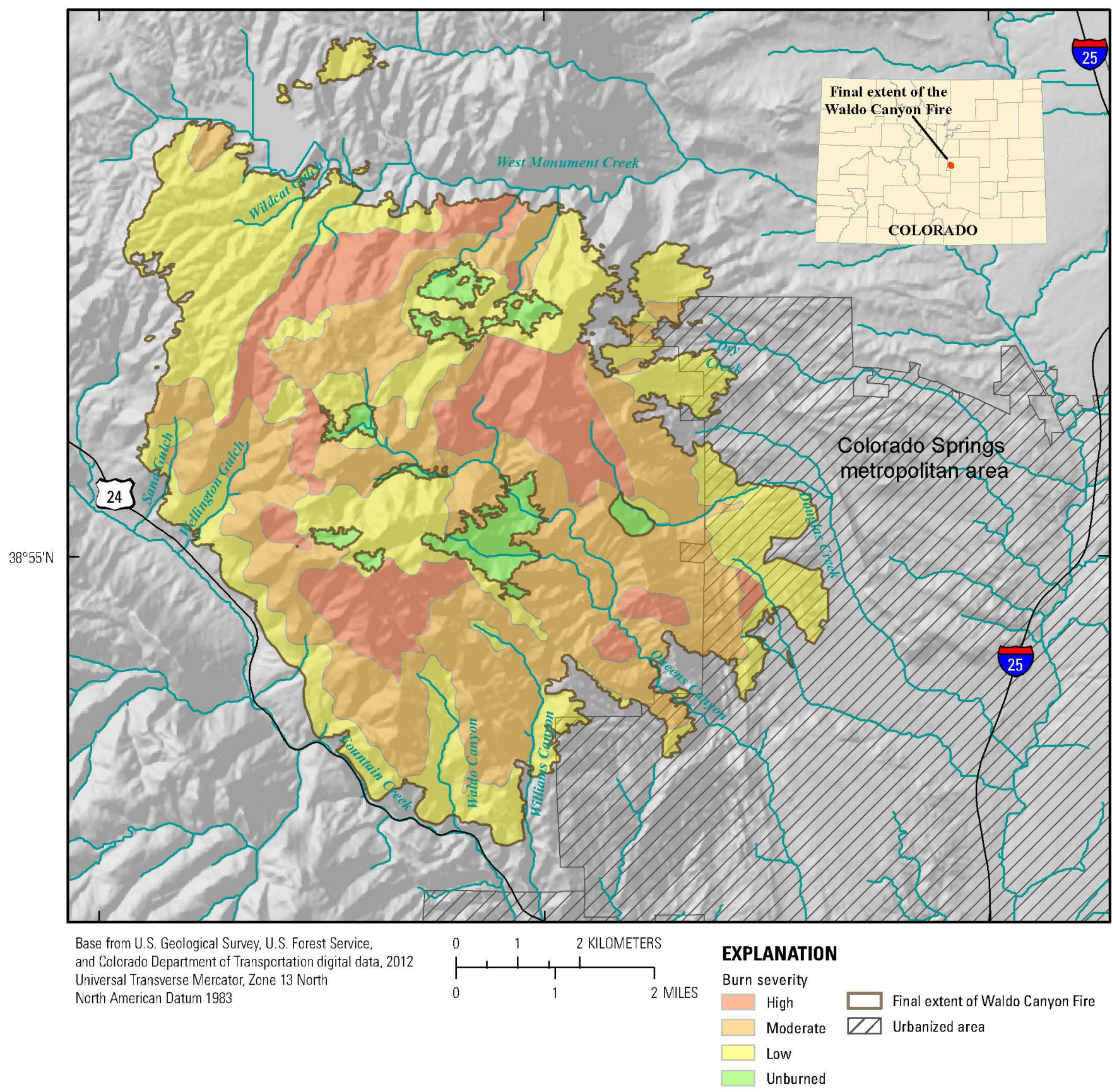

Figure 1. Location and severity of the 2012 Waldo Canyon fire near Colorado Springs, Colo. 
Table 1. Estimated debris-flow probabilities and volumes for the 2012 Waldo Canyon fire near Colorado Springs, Colo.

(mm, millimeters; km², square kilometers; \%, percent; $\mathrm{m}^{3}$, cubic meters; >, greater than)

\begin{tabular}{|c|c|c|c|c|c|c|c|c|c|c|}
\hline \multirow[b]{3}{*}{ Basin } & \multirow[b]{3}{*}{ Description } & & & & \multicolumn{2}{|c|}{ 2-year/1-hour precipitation } & \multirow{2}{*}{\multicolumn{2}{|c|}{$\frac{\text { 10-year/1-hour precipitation }}{42 \mathrm{~mm}}$}} & \multirow{2}{*}{\multicolumn{2}{|c|}{$\begin{array}{c}\text { 25-year/1-hour precipitatior } \\
48 \mathrm{~mm}\end{array}$}} \\
\hline & & \multicolumn{2}{|c|}{ Basin Pour Point } & \multirow{2}{*}{$\begin{array}{c}\text { Drainage } \\
\text { Area } \\
\left(\mathrm{km}^{2}\right)\end{array}$} & \multicolumn{2}{|c|}{$29 \mathrm{~mm}$} & & & & \\
\hline & & $\begin{array}{l}\text { Latitude } \\
\text { (de }\end{array}$ & $\begin{array}{l}\text { Longitude } \\
\text { ees) }\end{array}$ & & $\begin{array}{l}\text { Probability } \\
(\%)\end{array}$ & $\begin{array}{l}\text { Volume } \\
\left(\mathrm{m}^{3}\right)\end{array}$ & $\begin{array}{c}\text { Probability } \\
(\%)\end{array}$ & $\begin{array}{l}\text { Volume } \\
\left(\mathrm{m}^{3}\right)\end{array}$ & $\begin{array}{l}\text { Probability } \\
\text { (\%) }\end{array}$ & $\begin{array}{c}\text { Volume } \\
\left(\mathrm{m}^{3}\right)\end{array}$ \\
\hline 1 & Unnamed Creek 1 to Rampart Reservoir & 38.9806 & -104.9788 & 0.7 & 0 & 2,400 & 1 & 2,900 & 2 & 3,200 \\
\hline 2 & Unnamed Creek 2 to Rampart Reservoir & 38.9787 & -104.9722 & 0.3 & 1 & 1,500 & 1 & 1,800 & 2 & 2,000 \\
\hline 3 & Unnamed Creek 3 to Rampart Reservoir & 38.9736 & -104.9711 & 1.1 & 0 & 2,700 & 0 & 3,300 & 0 & 3,600 \\
\hline 4 & Wildcat Gulch & 38.9747 & -104.9570 & 3.9 & 0 & 6,200 & 0 & 7,700 & 1 & 8,400 \\
\hline 5 & Unnamed Creek to Nichol's Reservoir & 38.9702 & -104.9508 & 3.4 & 3 & 16,000 & 8 & 20,000 & 12 & 22,000 \\
\hline 6 & Unnamed Creek to Filtration Plant & 38.9728 & -104.9404 & 1.3 & 10 & 8,000 & 21 & 9,900 & 29 & 11,000 \\
\hline 7 & Unnamed Creek (Devil's Kitchen) & 38.9705 & -104.9208 & 2.9 & 5 & 17,000 & 12 & 21,000 & 18 & 23,000 \\
\hline 8 & Unnamed Creek (Pour Point near Water Tank) & 38.9708 & -104.9138 & 3.0 & 3 & 16,000 & 7 & 20,000 & 10 & 22,000 \\
\hline 9 & Dry Creek & 38.9478 & -104.8784 & 3.6 & 2 & 16,000 & 4 & 20,000 & 6 & 22,000 \\
\hline 10 & Douglas Creek & 38.9254 & -104.8634 & 5.5 & 22 & 46,000 & 41 & 57,000 & 51 & 62,000 \\
\hline 11 & Unnamed Creek (Aquaduct/30th Street) & 38.9002 & -104.8696 & 3.4 & 13 & 20,000 & 27 & 25,000 & 36 & 27,000 \\
\hline 12 & Queens Canyon & 38.8949 & -104.8895 & 20.6 & 24 & $>100,000$ & 45 & $>100,000$ & 55 & $>100,000$ \\
\hline 13 & Williams Canyon & 38.8637 & -104.9171 & 6.8 & 32 & 62,000 & 54 & 77,000 & 64 & 84,000 \\
\hline 14 & Waldo Canyon & 38.8764 & -104.9320 & 4.6 & 31 & 39,000 & 53 & 48,000 & 63 & 53,000 \\
\hline 15 & Unnamed Creek 1 to CO Hwy 24 (W of Milepost 295) & 38.8898 & -104.9587 & 1.4 & 54 & 11,000 & 74 & 14,000 & 82 & 16,000 \\
\hline 16 & Unnamed Creek 2 to CO Hwy 24 (W of Milepost 295) & 38.8889 & -104.9639 & 0.5 & 1 & 1,800 & 2 & 2,200 & 3 & 2,500 \\
\hline 17 & Unnamed Creek 3 to CO Hwy 24 (Cascade) & 38.8953 & -104.9712 & 2.0 & 54 & 17,000 & 74 & 21,000 & 82 & 23,000 \\
\hline 18 & Unnamed Creek 4 to CO Hwy 24 (S of Milepost 293) & 38.9052 & -104.9712 & 0.3 & 15 & 2,900 & 30 & 3,600 & 40 & 3,900 \\
\hline 19 & Unnamed Creek 5 to CO Hwy 24 (NW of Milepost 293) & 38.9078 & -104.9732 & 0.7 & 33 & 6,200 & 55 & 7,700 & 65 & 8,500 \\
\hline 20 & Unnamed Creek 6 to CO Hwy 24 (NW of Milepost 293) & 38.9122 & -104.9766 & 0.9 & 45 & 8,100 & 67 & 10,000 & 76 & 11,000 \\
\hline 21 & Wellington Gulch & 38.9171 & -104.9851 & 4.5 & 48 & 41,000 & 69 & 52,000 & 78 & 56,000 \\
\hline 22 & Sand Gulch & 38.9205 & -104.9935 & 2.9 & 6 & 16,000 & 13 & 20,000 & 18 & 22,000 \\
\hline
\end{tabular}

